\title{
Oral erythroplakia harbouring a squamous cell carcinoma
}

\author{
Rupsa Das, ${ }^{1}$ Satya Ranjan Misra, ${ }^{1}$ Pavitra Baskaran, ${ }^{2}$ Neeta Mohanty $\left({ }^{3}{ }^{3}\right.$
}

${ }^{1}$ Oral Medicine and Radiology, Siksha 0 Anusandhan University Institute of Dental Sciences, Bhubaneswar, Odisha, India ${ }^{2}$ The Tooth World, Chennai, Tamil Nadu, India

${ }^{3}$ Oral Maxillofacial Pathology and Microbiology, Siksha 0 Anusandhan University Institute of Dental Sciences, Bhubaneswar, Odisha, India

Correspondence to Professor Neeta Mohanty; neetamohanty@soa.ac.in

Accepted 10 January 2022

\section{DESCRIPTION}

Erythroplakia is a rare oral lesion that presents as a well-defined, velvety-textured, homogenously red patch considered a potentially malignant disorder. ${ }^{1}$ Oral erythroplakia needs to be differentiated from other erythematous oral lesions, especially of inflammatory origin, often by histopathological evaluation. It has been emphasised that a persistent asymptomatic oral erythroplasic patch when present in high-risk sites such as the ventral surface of the tongue or the floor of the mouth may be the earliest and primary sign of oral cancer. ${ }^{2}$ The middle-aged and the elderly are usually affected, with a slight male gender predilection. The prevalence is only about $0.02 \%-0.2 \%$. The aetiopathogenesis is unclear, yet a strong association with usage of tobacco and alcohol has been cited in the literature. ${ }^{1}$ In about $85 \%$ of cases, histological signs of squamous cell carcinoma are seen on histological evaluation. ${ }^{2}$ Erythroplakia is generally a diagnosis of exclusion and needs to be differentiated from other red oral lesions (figure 1), such as erosive oral lichen planus, erythematous candidiasis, oral mucositis, pemphigus vulgaris, mucous membrane pemphigoid and systemic lupus erythematosus, with biopsy performed in addition to a thorough history-taking session and meticulous clinical examination.

A 51-year-old male patient reported with burning sensation in the tongue for 2 months. His medical history was unremarkable, with a history of chronic use of smoking tobacco and drinking alcohol. A well-demarcated, irregular, erythematous patch was seen on the left side of the dorsum of the tongue crossing the midline, almost homogenously red in colour, measuring about $5 \times 3 \mathrm{~cm}$ in size, with smooth surface and velvety texture, raised everted borders laterally, rough, indurated in consistency, and slightly tender on palpation (figure 2). A provisional

\section{Differential Diagnosis of Erythroplakia}

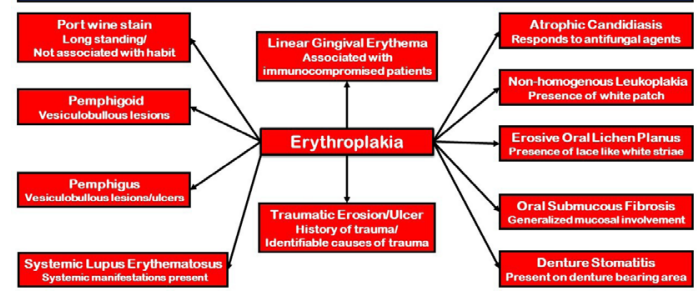

Figure 1 Flow diagram showing the differential diagnosis of oral erythroplakia.

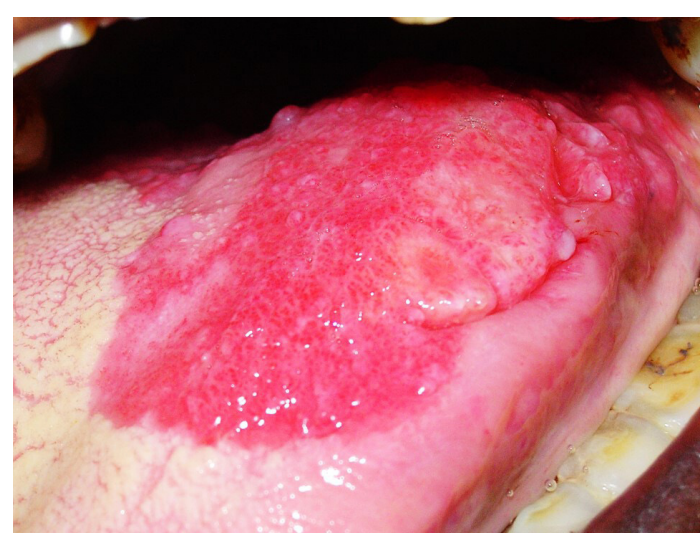

Figure 2 An irregular erythematous patch seen on the left side of the dorsum of the tongue with raised indurated borders medially.

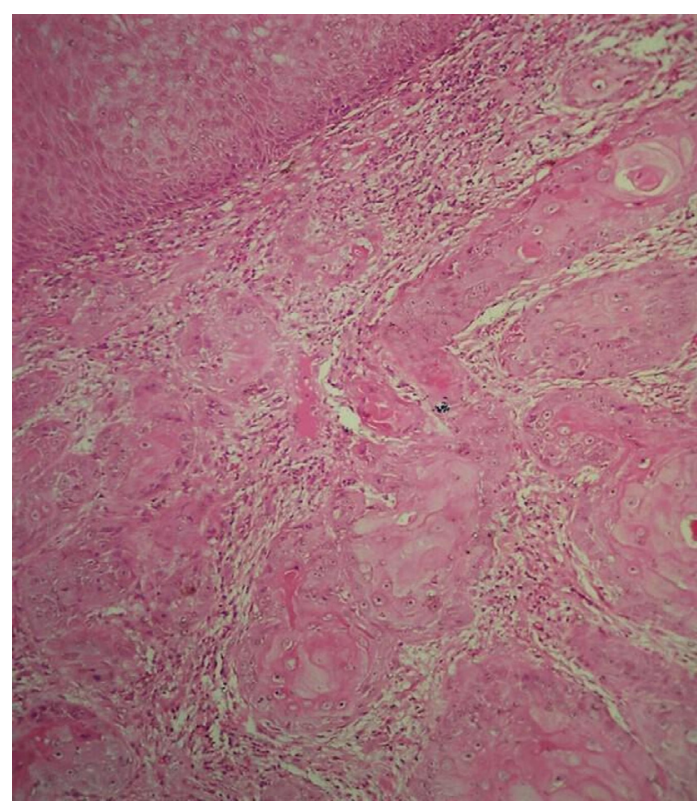

Figure 3 Squamous cell carcinoma.

\section{Learning points}

Oral erythroplakia is a rare lesion.

- It is the oral potentially malignant disorder with the strongest malignant potential and is often histologically diagnosed as squamous cell carcinoma.

- An idiopathic red lesion in the oral cavity needs to be histologically evaluated. 
diagnosis of erythroplakia with oral squamous cell carcinoma was made and an incisional biopsy was performed. Histological evaluation revealed hyperplastic, stratified squamous epithelial cells and infiltration of malignant epithelial cells in the connective tissue stroma with keratin pearl formation, suggestive of well-differentiated squamous cell carcinoma (figure 3 ). The patient was then referred to a surgical oncologist, underwent surgery and radiotherapy, but was subsequently lost to follow-up.

Contributors RD examined the patient. PB performed the biopsy. NM interpreted the histological findings. SRM prepared the manuscript.

Funding The authors have not declared a specific grant for this research from any funding agency in the public, commercial or not-for-profit sectors.

Competing interests None declared.
Patient consent for publication Obtained.

Provenance and peer review Not commissioned; externally peer reviewed.

Case reports provide a valuable learning resource for the scientific community and can indicate areas of interest for future research. They should not be used in isolation to guide treatment choices or public health policy.

\section{ORCID iD}

Neeta Mohanty http://orcid.org/0000-0002-7449-3974

\section{REFERENCES}

1 Reichart PA, Philipsen HP. Oral erythroplakia--a review. Oral Oncol 2005;41:551-61.

2 Acharya S, Singh S, Bhatia SK. Association between smokeless tobacco and risk of malignant and premalignant conditions of oral cavity: a systematic review of Indian literature. J Oral Maxillofac Pathol 2021:25:371.

3 Abati S, Bramati C, Bondi S, et al. Oral cancer and precancer: a narrative review on the relevance of early diagnosis. Int J Environ Res Public Health 2020;17:9160.

Copyright 2022 BMJ Publishing Group. All rights reserved. For permission to reuse any of this content visit

https://www.bmj.com/company/products-services/rights-and-licensing/permissions/

BMJ Case Report Fellows may re-use this article for personal use and teaching without any further permission.

Become a Fellow of BMJ Case Reports today and you can:

- Submit as many cases as you like

- Enjoy fast sympathetic peer review and rapid publication of accepted articles

- Access all the published articles

Re-use any of the published material for personal use and teaching without further permission

Customer Service

If you have any further queries about your subscription, please contact our customer services team on +44 (0) 2071111105 or via email at support@bmj.com.

Visit casereports.bmj.com for more articles like this and to become a Fellow 